\title{
Potential impacts of the 2010 Deepwater Horizon oil spill on subtidal oysters in the Gulf of Mexico
}

\author{
Jonathan H. Grabowski ${ }^{1, *}$, Sean P. Powers ${ }^{2}$, Henry Roman ${ }^{3}$, Shahrokh Rouhani ${ }^{4}$ \\ ${ }^{1}$ Northeastern University, Marine Science Center, 430 Nahant Road Nahant, MA 01908, USA \\ ${ }^{2}$ Department of Marine Sciences, University of South Alabama and the Dauphin Island Sea Lab, 1011 Bienville Blvd., \\ Dauphin Island, AL 36528, USA \\ ${ }^{3}$ Industrial Economics, Inc., 2067 Massachusetts Ave., Cambridge, MA 02140, USA \\ ${ }^{4}$ NewFields, 1349 W. Peachtree Street, Suite 2000, Atlanta, GA 30309, USA
}

\begin{abstract}
The explosion of the Deepwater Horizon (DWH) drilling platform initiated an unprecedented chain of environmental perturbations that threatened sensitive nearshore habitats in the northern Gulf of Mexico in 2010. Here, we examined subtidal oyster reef populations monitored by state resource agencies prior to and after the DWH incident in the spring-summer of 2010. Fishery-independent surveys were conducted in each of the following Gulf States using either diver-collected quadrat samples (Louisiana, Mississippi, Florida) or dredge surveys (Texas) at fixed sites to assess trends in oyster density of recently settled (spat), juvenile to young adult (seed), or adult (market) oysters. Compared to baseline values (average 2006-2009), the densities of spat, seed, and market oysters were extremely low in 2010, with little recovery in 2011 and 2012 in areas within the central portion of the northern Gulf of Mexico (eastern Louisiana-Mississippi). In contrast, densities of all oyster size classes in western Louisiana and Texas (outside the footprint of oil or freshwater release) and juvenile oysters in Apalachicola Bay, Florida, revealed no consistent pattern of change in 2010 compared to baseline levels in 2006-2009. Thus, major declines in oyster populations occurred within the northern Gulf of Mexico in summer 2010, and populations remained low through 2012. The spatial footprint of this decline is largely coincident with the oiling and freshwater diversion response activities associated with the DWH incident, although many potential confounding factors are also considered. Fisheries-independent datasets offer much-needed baseline data that can be used to assess potential impacts from disturbances.
\end{abstract}

KEY WORDS: Crassostrea virginica - Deepwater Horizon - Eastern oyster - Gulf of Mexico · Oil spill · Perturbation

\section{INTRODUCTION}

The interface of marine and terrestrial biomes represents one of the more productive environments on Earth. Degradation of nearshore marine habitats that occurs within this interface poses a significant threat to the sustainable provision of natural resources from them. The release of pollutants in marine environments continues to represent a major source of degradation in many nearshore systems as a result of both discrete and chronic exposure to contaminants.

\footnotetext{
*Corresponding author: j.grabowski@neu.edu
}

In April 2010, the drilling platform Deepwater Horizon (DWH) exploded in the north-central Gulf of Mexico (GoM) and resulted in an oil spill that lasted for $87 \mathrm{~d}$ and released hundreds of millions of liters of Louisiana sweet crude oil into the GoM (US District Court 2014, 2015). The inshore advection and subsequent deposition of the oil resulted in oiling of many beaches and marshes located from western Louisiana to the Florida Panhandle. In response to the oil spill, several activities were conducted to mitigate the amount of oiling, including applying almost 7 million

(C) The authors 2017. Open Access under Creative Commons by Attribution Licence. Use, distribution and reproduction are unrestricted. Authors and original publication must be credited. 
liters of dispersants in offshore waters (OSAT 2010), releasing freshwater from diversion structures east and west of the Mississippi River, and initiating other response and cleanup activities within nearshore environments.

When anthropogenic impacts occur, a primary challenge is quantifying the magnitude of each impact on ecosystem functions and the associated goods and services. Furthermore, perturbations that occur in nearshore waters often negatively impact coastal ecosystem services such as fisheries landings. While informative, fisheries landing data can be challenging to incorporate into population and stock assessment models due to the difficulties of normalizing these data to standardize for differences in effort among years. This limitation has motivated many resource agencies to collect fisheries-independent data using seasonal and annual surveys of commercially and recreationally valuable fishery species.

By 2006, each US state bordering the GoM (hereafter referred to as 'Gulf states') had implemented subtidal oyster abundance surveys using dredge (Texas) or quadrat (Louisiana, Mississippi, Alabama, Florida) sampling efforts. Although oyster sampling methodologies and sampling effort varied across this region and these differences must be considered when interpreting the data, the surveys do provide baseline data on juvenile and adult oyster densities for multiple years prior to the DWH spill. The surveys also span across the coastal margin of the GoM, thereby encompassing regions potentially impacted by and adjacent to the spill and resulting in a design analogous to that of a before-after-control-impact (BACI) study. Other important variables and related covariates may have influenced oyster survival during or after the spill. For instance, each state manages its oyster resources differently, from decisions around public vs. private leasing and shell planting to historic harvesting regulations. The Gulf States also responded differently regarding opening and even relaxing fishing restrictions vs. closing the fishery directly during and right after the spill. Still, the state oyster surveys offer an unprecedented opportunity to explore the potential impacts of this historically large spill and associated response activities, such as the opening of freshwater diversions in 2010 in southeastern Louisiana, on subtidal oyster reef habitat throughout the GoM.

Within most estuaries in the northern GoM and the Atlantic Ocean, oysters form reefs and provide ecosystem services that human societies value and rely upon (Grabowski et al. 2012). For instance, oysters enhance the recruitment and growth of economically valuable and ecologically important finfish and crustaceans, thereby augmenting the productivity of these species (Coen et al. 1999, Breitburg et al. 2000, Harding \& Mann 2001, Peterson et al. 2003, Soniat et al. 2004, Grabowski et al. 2005, Tolley \& Volety 2005). Oyster reefs concentrate bottom deposits of feces that promote bacterially mediated denitrification, thereby counteracting anthropogenic nitrogen loading (Newell et al. 2002, Piehler \& Smyth 2011, Carmichael et al. 2012, Kellogg et al. 2013, Smyth et al. 2013). When oyster reefs filter the water and enhance light penetration, they promote other valuable estuarine habitats such as submerged aquatic vegetation (Newell 1988, Everett et al. 1995, Newell \& Koch 2004, Carroll et al. 2008, Wall et al. 2008). Thus, large-scale perturbations that cause widespread oyster mortality and the degradation of oyster reef habitat also can result in the loss of these valuable ecosystem services. Given that an ecosystem services approach has been suggested as a possible mechanism to address the natural resource damages caused by the DWH spill (National Research Council 2013), quantifying the magnitude of damages to species such as the eastern oyster Crassostrea virginica is an important first step.

Here we assessed nearshore subtidal oyster reef populations in the GoM using fisheries-independent data collected before (2006-2009) and after (20102012) the DWH spill. We excluded data collected before 2006 in our baseline period because of the impacts to the GoM from hurricanes Katrina and Rita. Moreover, including years prior to 2006 when these major disturbances occurred would potentially confound our efforts to use the baseline period to predict what oyster abundances would have been in 2010-2012 in the absence of the spill. We compared baseline and post-spill estimates of spat-, seed-, and market-sized oysters from Texas to Florida. Thus, we were able to examine potential impacts from the DWH spill and response activities in areas located proximal to the spill (i.e. Louisiana and Mississippi) vs. those that were more distant and not directly impacted by it (i.e. Texas and Florida).

\section{MATERIALS AND METHODS}

\section{Data collection}

Oyster abundance data from 2006-2012 were obtained from the marine resources management agency for each of the Gulf States (Fig. 1). These data were collected using the standard methods histori- 


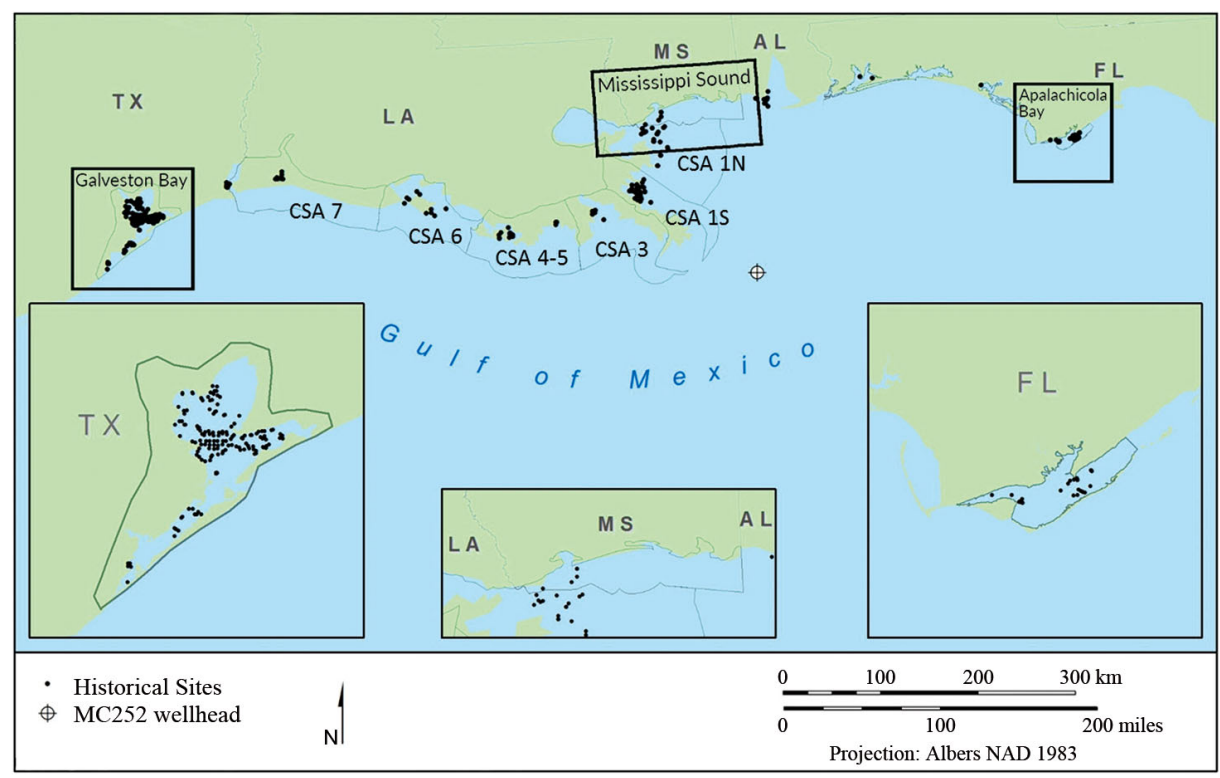

Fig. 1. Location of sampling sites in each state and the MC252 (Deepwater Horizon) wellhead. Coastal study areas (CSAs) are depicted in Louisiana (LA). TX: Texas, MS: Mississippi, AL: Alabama, FL: Florida

\section{Louisiana}

The Louisiana Department of Wildlife and Fisheries (LA-DWF) annually estimated oyster abundance at $\sim 100$ sites on public oyster grounds each July from 2006 to 2012. Samples were collected using $1.0 \mathrm{~m}^{2}$ quadrats randomly placed on an oyster reef at each site. A SCUBA diver removed all oysters within the frame to a depth of approximately $7.5-10 \mathrm{~cm}$ and brought the sample to the surface where it was processed. The height of all living oysters was measured and recorded in $5 \mathrm{~mm}$ increments (e.g. 0-4, 5-9 $\mathrm{mm}$, etc.). At least 2 replicate $1 \mathrm{~m}^{2}$ samples were conducted at each site.

While LA-DFW conducted oyster surveys of the 1.68 million acres ( 680000 ha) of public bottom available for harvest, an additional $\sim 400000$ acres ( 162 000 ha) are under lease. The public oyster grounds are typically used as a source of sublegal oysters that are transplanted to private leases, although they can also account for a substantial proportion of oyster landings in Louisiana (e.g. public grounds accounted for $47 \%$ of oyster landings in Louisiana in 2007; LA-DWF 2011). Thus, the public oyster grounds are considered critically important to the Louisiana oyster resource (LA-DWF 2011).

\section{Mississippi}

In Mississippi, 5 reefs were surveyed annually by the Mississippi Department of Marine Resources at multiple (14-20) randomly selected subplots on the reefs. At each site, a SCUBA diver collected oysters using a $1 \mathrm{~m}^{2}$ quadrat on each reef. All oysters within the quadrat to a depth of 7.5-10 cm were collected and brought to the surface for processing. SHs of all living oysters were recorded to the nearest $1 \mathrm{~mm}$.

\section{Florida}

We obtained quadrat data from the Florida Department of Agriculture and Consumer Services Division for Aquaculture for 23 sites in Apalachicola, Penoysters. 
sacola, and St. Andrew's Bays. Transects were established that traversed oyster reefs at each site, and multiple (up to 20) $1 \mathrm{~m}^{2}$ quadrat samples were selected by throwing the quadrat frame overboard. Divers removed oysters to a depth of approximately $15 \mathrm{~cm}$. SHs of all living oysters were rounded down to the nearest $5 \mathrm{~mm}$. Density estimates per $1 \mathrm{~m}^{2}$ were then calculated for oysters $\geq 50 \mathrm{~mm}, \geq 75 \mathrm{~mm}$, and overall.

\section{Data processing}

We attempted to compile these data for each state in such a manner that they were as consistent as possible across regions. This effort was limited in instances where the data were collected using a different field method (e.g. dredge data from Texas), or where we received summarized data from the state and could not reclassify the data by our defined size classes (e.g. density data from Florida). Where possible, state oyster abundance data were compiled into 3 categories: spat (generally $<25 \mathrm{~mm} \mathrm{SH}$ ), seed (generally $25-74 \mathrm{~mm} \mathrm{SH}$ ), and market $(\geq 75 \mathrm{~mm} \mathrm{SH}$; Table 1). All abundance metrics for Louisiana, Mississippi, and Florida were converted to the number of living oysters of a given size class per $1 \mathrm{~m}^{2}$. These results were used to calculate mean oyster density at each site. Because oyster dredge efficiency can vary with oyster size and reef properties (Powell et al. 2002), oyster data from Texas provide an index of density rather than a quantitative estimate of oyster density.

The following computations were conducted to standardize comparisons among the different regions and periods. In Texas, abundances of seed- and market-sized oysters were calculated as mean abundance site ${ }^{-1} \mathrm{yr}^{-1}$, scaled by the number of oysters in the sample. The seed and market data had to be scaled to account for the fact that only the first 19 randomly chosen oysters were measured for SH. Spat abundance, which was only measured on a subset of

Table 1. Size classes of eastern oysters Crassostrea virginica (based on shell height in $\mathrm{mm}$ ) used to analyze the historical density data for each Gulf State

\begin{tabular}{|lccc|}
\hline State & Market & Seed & Spat \\
\hline Texas & 75 & $26-74$ & $5-25$ (index) \\
Louisiana & 75 & $25-74$ & $0-24$ \\
Mississippi & 75 & $25-74$ & $0-24$ \\
Alabama & 75 & $26-74$ & $0-25$ \\
Florida & 75 & $50-74$ & $0-49$ \\
\hline
\end{tabular}

the seed and/or market oysters in each dredge, was converted to an index that we calculated as the total number of spat counted in each dredge divided by the proportion of oysters examined for spat in that dredge (a maximum of 10 oysters).

Louisiana has 7 widely recognized coastal study areas (CSAs); the analyses were conducted for CSA $1 \mathrm{~N}, \mathrm{CSA} 1 \mathrm{~S}$, and CSA 3 individually, whereas CSAs 4-7 were combined because these CSAs had relatively few sites (Fig. 1). Most of the sites in CSA 4 are towards its western edge (Fig. 1), where little to no oil was observed using the Shoreline Cleanup Assessment Technique observations (Michel et al. 2013). In Mississippi, only 5 reefs in Mississippi Sound were surveyed consistently over the time period we investigated. However, there were many replicates (14 to 20) per reef that resulted in robust mean abundance measurements.

In Florida, oyster abundances in each size category were calculated from the density estimates supplied by the state and multiplying the overall density by the proportion of oysters in each size category (the proportion of spat oysters was determined by subtracting the percentage of oysters $\geq 50 \mathrm{~mm}$ from $100 \%)$. Finally, the data from Texas and Florida were collected year-round; thus, we limited data from these states to samples collected from August to November to examine only the late-summer reproductive period.

\section{Statistical analyses}

A series of paired $t$-tests were used in each region to test whether the densities of spat-, seed-, and marketsized oysters collected from reefs in the baseline period (2006-2009) differed from the densities of each respective size class in 2010, 2011, and 2012. Due to the differences in how each state sampled oysters and potential regional differences in site characteristics, separate analyses were conducted for the following 7 regions: Galveston Bay, Texas; western Louisiana (CSAs 7-4), CSA 3, CSA 1S, CSA 1N; Mississippi Sound, Mississippi; and Apalachicola Bay, Florida. Within each region, sites were treated as independent replicates and had to have been sampled in the comparison year (2010, 2011, or 2012) and at least 2 out of the 4 baseline years (2006-2009) to be included in these analyses (see Table S1 in the Supplement at www.int-res.com/ articles/suppl/m576p163_supp.pdf for a breakdown of which sites were sampled in each year). We created this site selection criterion because $86.3 \%$ of sites in Texas were sampled in either 1 or 2 years. Including 
only sites that were sampled in at least 3 or 4 years during the baseline period would have significantly reduced our ability to detect differences. Meanwhile, in Louisiana, Mississippi, and Florida, $77 \%$ of sites were sampled in all 4 years, and $84 \%$ were sampled in 3 or more years of the baseline period.

Because the northern GoM was likely still recovering from hurricanes Katrina and Rita in 2006, we assessed whether oyster densities from 2006 should be included in the baseline period. In particular, we conducted an additional series of analyses in which we excluded the 2006 data and compared the 2 sets of results. Excluding 2006 from the baseline period resulted in almost identical results and had no effect on the overall conclusions of our study. Thus, we decided to include 2006 in our baseline period. For a particular site, the mean density during the baseline period was compared to 2010, 2011, and/or 2012. A p-value of $<0.1$ was considered significant in accordance with guidance for environmental impact studies (Underwood 1989). All analyses were conducted in R (v. 3.2.3).

We did not adjust the alpha level to avoid spurious results because of the mathematical, logical, and practical concerns relative to ecological studies raised by Moran (2003). For instance, ecological field studies, and especially environmental impact studies, often have small numbers of replicates due to the financial and logistical challenges associated with achieving additional replication and hence often have low statistical power. Moran (2003) also pointed out an important paradox associated with conducting additional tests when the alpha level is adjusted-the more tests that one conducts, the probability of finding a significant result decreases dramatically.

\section{RESULTS}

In Galveston Bay, Texas, indices of oyster densities were largely similar before vs. immediately after the spill occurred in 2010. This survey region was the farthest away from the spill area (Fig. 1). In particular, indices of oyster densities of all 3 size categories during the baseline period (i.e. 2006-2009) did not differ from those in 2010 in this region (Table 2, Fig. 2). In-

Table 2. Paired $t$-test results for spat-, seed-, and market-sized eastern oysters Crassostrea virginica by state or region. For each analysis, $\mathrm{n}$ (the number of paired sites compared in the analysis), $\mathrm{p}$-value (significant values at $\mathrm{p}<0.10$ are in bold), and the percent difference of the baseline (2006-2009) less the comparison year (2010, 2011, or 2012) divided by the baseline (\% Diff) are displayed. Alabama (Mobile Bay) data are not included because sample sizes were too small to provide meaningful comparisons. TX: Texas, LA: Louisiana, CSA: coastal study area, FL: Florida

\begin{tabular}{|c|c|c|c|c|c|c|c|c|c|}
\hline \multirow[b]{2}{*}{ Region } & \multicolumn{3}{|c|}{- Spat } & \multicolumn{3}{|c|}{ Seed } & \multirow[b]{2}{*}{$\mathrm{n}$} & \multicolumn{2}{|c|}{ — Market- } \\
\hline & $\mathrm{n}$ & $\mathrm{p}$ & $\%$ Diff & $\mathrm{n}$ & $\mathrm{p}$ & \% Diff & & $\mathrm{p}$ & $\%$ Diff \\
\hline \multicolumn{10}{|l|}{2010} \\
\hline Galveston Bay, TX & 25 & 0.11 & 127.8 & 25 & 0.33 & 16.3 & 25 & 0.44 & -4.6 \\
\hline LA CSA $7-4$ & 22 & 0.23 & -35.8 & 22 & 0.19 & -27.0 & 22 & 0.09 & -52.4 \\
\hline LA CSA 3 & 6 & 0.02 & -86.9 & 6 & 0.09 & -78.9 & 6 & 0.27 & 42.7 \\
\hline LA CSA 1S & 29 & $<0.001$ & -96.1 & 29 & $<0.001$ & -80.3 & 29 & $<0.001$ & -79.0 \\
\hline LA CSA $1 \mathrm{~N}$ & 12 & 0.02 & -85.7 & 12 & 0.04 & -87.1 & 12 & 0.01 & -76.6 \\
\hline Mississippi & 5 & 0.03 & -77.4 & 5 & 0.002 & -80.8 & 5 & 0.01 & -80.5 \\
\hline Apalachicola Bay, FL & 6 & 0.16 & -20.6 & 6 & 0.11 & -37.5 & 6 & 0.04 & -56.1 \\
\hline \multicolumn{10}{|l|}{2011} \\
\hline Galveston Bay, TX & 23 & 0.02 & -73.3 & 23 & 0.32 & -18.4 & 23 & 0.47 & 5.6 \\
\hline LA CSA $7-4$ & 28 & 0.01 & -49.8 & 28 & 0.02 & -52.7 & 28 & 0.05 & -52.1 \\
\hline LA CSA 3 & 6 & 0.12 & 71.5 & 6 & 0.11 & 149.0 & 6 & 0.30 & 45.1 \\
\hline LA CSA 1S & 29 & $<0.001$ & -99.0 & 29 & $<0.001$ & -97.5 & 29 & 0.001 & -66.1 \\
\hline LA CSA $1 \mathrm{~N}$ & 13 & 0.01 & -95.1 & 13 & 0.03 & -89.5 & 13 & 0.004 & -92.4 \\
\hline Mississippi & 5 & 0.01 & -84.3 & 5 & 0.02 & -45.8 & 5 & 0.12 & 100.6 \\
\hline Apalachicola Bay, FL & 5 & 0.26 & -21.0 & 5 & 0.15 & -31.6 & 5 & 0.02 & -44.1 \\
\hline \multicolumn{10}{|l|}{2012} \\
\hline Galveston Bay, TX & 26 & 0.12 & -51.6 & 26 & 0.34 & 27.8 & 26 & 0.33 & 26.1 \\
\hline LA CSA $7-4$ & 28 & 0.003 & -56.0 & 28 & 0.001 & -69.0 & 28 & 0.01 & -78.7 \\
\hline LA CSA 3 & 6 & 0.15 & 112.9 & 6 & 0.37 & -12.2 & 6 & 0.20 & 235.4 \\
\hline LA CSA 1S & 29 & $<0.001$ & -86.9 & 29 & $<0.001$ & -99.5 & 29 & $<0.001$ & -84.7 \\
\hline LA CSA $1 \mathrm{~N}$ & 13 & 0.10 & -47.3 & 13 & 0.05 & -86.0 & 13 & 0.01 & -90.0 \\
\hline Mississippi & 4 & 0.17 & 25.2 & 4 & 0.01 & -71.3 & 4 & 0.19 & -16.6 \\
\hline Apalachicola Bay, FL & 5 & 0.07 & -60.9 & 5 & 0.01 & -86.6 & 5 & 0.01 & -70.0 \\
\hline
\end{tabular}



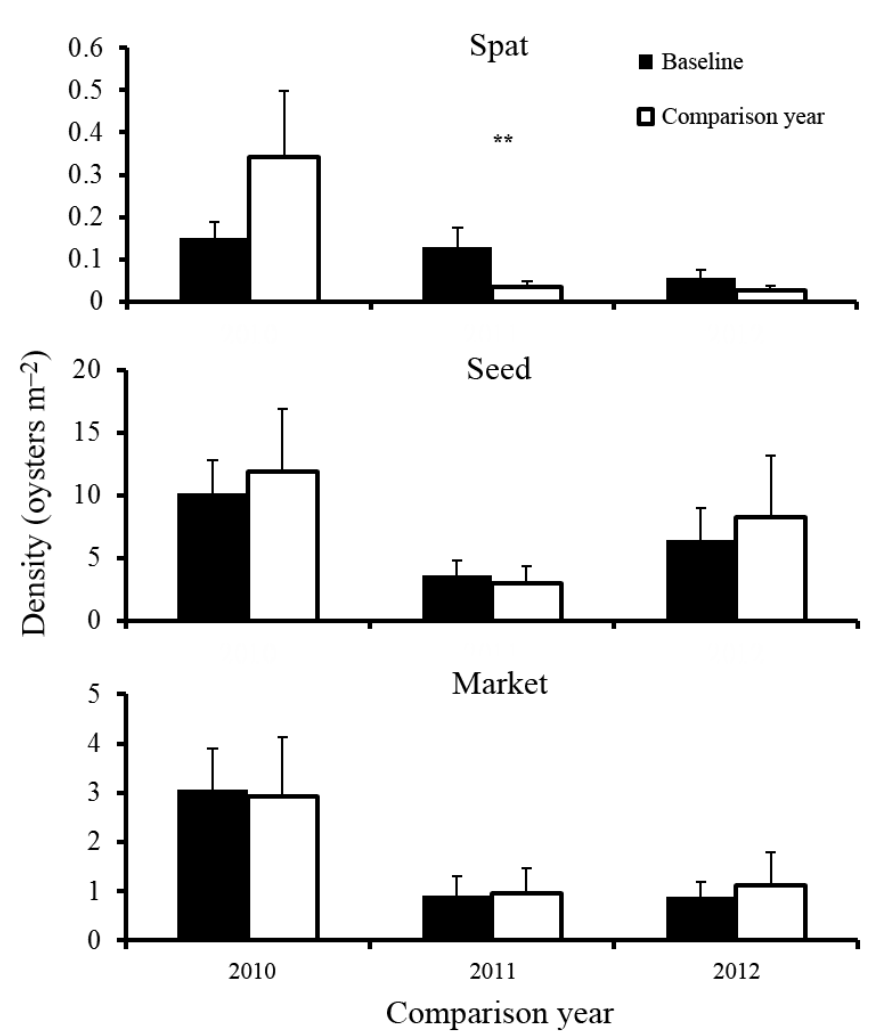

Fig. 2. Pairwise comparisons of spat-, seed-, and marketsized eastern oyster Crassostrea virginica densities (oysters $\mathrm{m}^{-2}$ ) at sites in Galveston Bay, Texas, during the baseline period (2006-2009) vs. 2010, 2011, and 2012. Significant $t$-tests are identified at ${ }^{*} \mathrm{p}<0.1,{ }^{* *} \mathrm{p}<0.05$. Error bars indicate $+1 \mathrm{SE}$

dices of spat, seed, and market oyster densities also did not change in either 2011 or 2012 relative to the baseline period other than lower spat in 2011.

Densities of spat and seed oysters directly after the spill in 2010 did not differ from the baseline period in western Louisiana (CSAs 7-4), which was at the far western edge of the spill footprint (Table 2, Fig. 3). Densities of market-size oysters in this region were significantly lower in 2010 than the baseline period. In this region, oyster densities in 2011 and 2012 were significantly lower than those in the baseline period for all 3 size classes.

Most of the remaining regions that were within the footprint of the spill had lower spat, seed, and adult oyster densities immediately after the spill in 2010 than the baseline period, and differences between the 2 periods were greatest east of the Mississippi River in Louisiana (Fig. 1). Spat and seed densities were significantly lower at the western edge of the spill in Louisiana's CSA 3 in 2010 relative to the baseline period, but did not differ in 2011 and 2012 (Table 2, Fig. 4). The density of market oysters in this

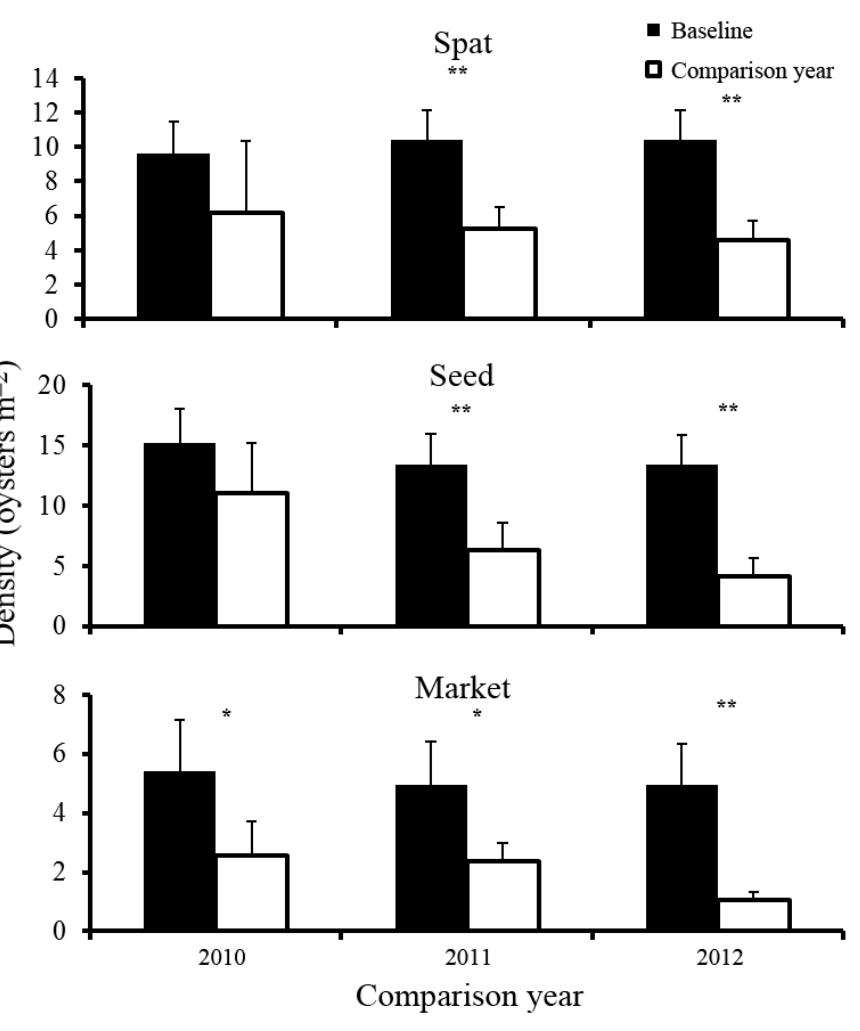

Fig. 3. As in Fig. 2, but for CSAs 7-4, Louisiana

region did not change substantially until it increased by over $200 \%$ in 2012 .

Densities of all size classes of oysters sampled east of the Mississippi River in Louisiana were significantly lower and persistently low throughout the post-oiling monitoring period. In CSA 1S, densities of all 3 size classes were $79-96 \%$ lower in 2010 relative to the baseline period (Table 2, Fig. 5). Furthermore, all 3 size classes within CSA $1 \mathrm{~S}$ remained significantly (85-100\%) lower than the baseline period through 2012, with spat and seed oysters largely absent from almost all quadrat samples. In CSA $1 \mathrm{~N}$, densities of all 3 size classes of oysters were $77-87 \%$ lower in 2010 relative to the baseline period, and seed and market densities remained significantly lower through 2012 (Table 2, Fig. 6). Spat levels in CSA $1 \mathrm{~N}$ were extremely low in 2011 but did not significantly differ from the baseline period in 2012 even though there was a trend of fewer spat during this period $(\mathrm{p}=0.10)$.

In Mississippi, densities of all 3 size classes of oysters were lower in 2010 by $77-81 \%$ relative to the baseline period (Table 2, Fig. 7). In 2011, densities of spat in Mississippi Sound remained significantly lower than the baseline period, whereas the 2011 density of market oysters did not differ from the base- 


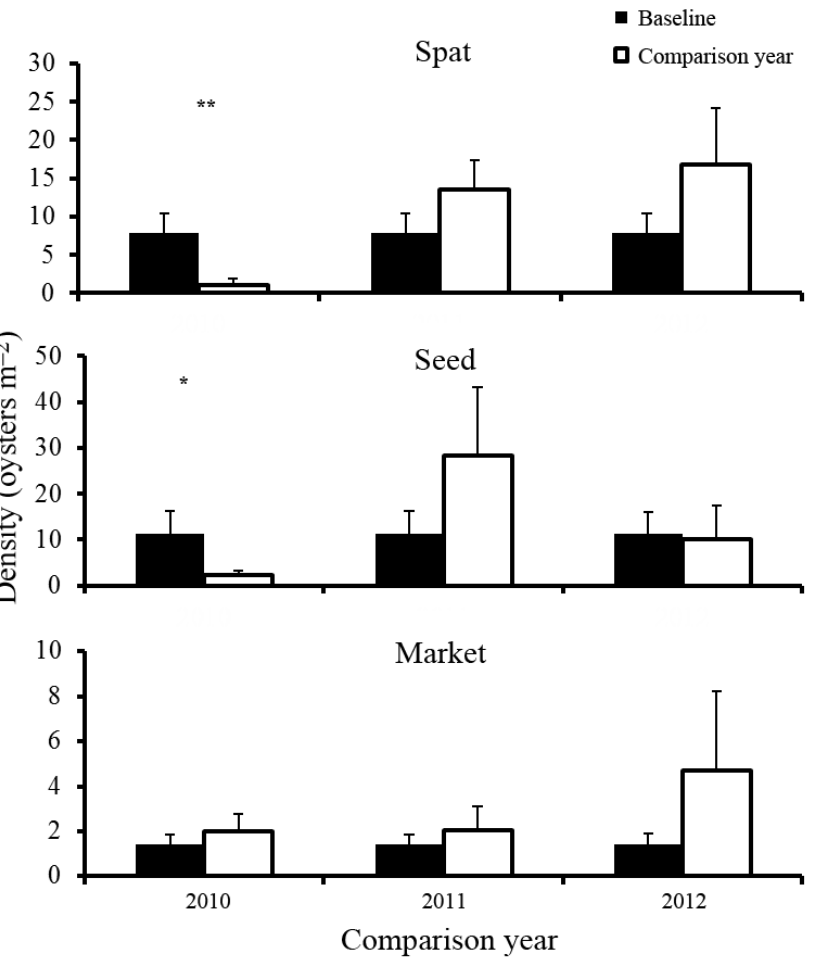

Fig. 4. As in Fig. 2, but for CSA 3, Louisiana

line period. In 2012, only densities of seed oysters in Mississippi were significantly lower than the baseline period.

At the far eastern extreme of the oiling footprint in Apalachicola Bay, market oyster densities in 2010 were significantly lower by $56 \%$ than those for the baseline period, whereas spat and seed oyster densities did not differ between the baseline and 2010 (Table 2, Fig. 8). Market oyster densities in 2011 and 2012 were also significantly lower than the baseline period. Meanwhile, spat and seed oyster densities in 2011 did not differ from the densities of those size classes in 2011. However, both of these size classes were significantly lower in 2012 than they were in the baseline period.

\section{DISCUSSION}

Although the fisheries-independent oyster survey methods used by state resource agencies from Texas to Florida differ, collectively they offer critical baseline and post-impact information on oyster populations from within and adjacent to the DWH spill impact area. Specifically, they provide an opportunity to evaluate the potential impacts of an unprecedented spill on a critical estuarine habitat that is val-

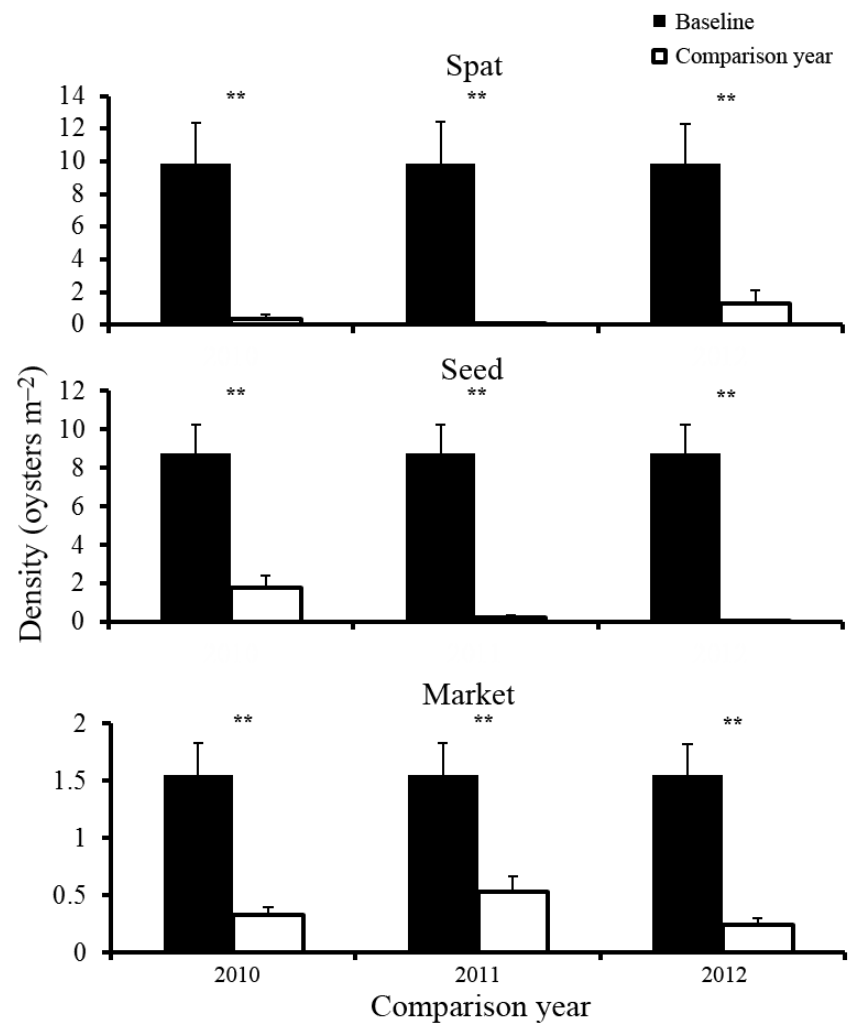

Fig. 5. As in Fig. 2, but for CSA 1S, Louisiana

ued not only as a harvestable oyster resource that can be extracted, but also for the ecosystem services that intact oyster reefs provide, such as stabilizing shorelines, removing anthropogenic nitrogen, and providing habitat for juvenile and adult finfish and crustaceans (Coen et al. 1999, Peterson \& Lipcius 2003, Peterson et al. 2003, Piazza et al. 2005, Piehler \& Smyth 2011, Grabowski et al. 2012). The results from these surveys collectively suggest that declines in oyster densities were typically greatest and most persistent in the coastal regions with highest oiling from the DWH spill and associated response activities such as the release of freshwater.

The opening of the Caernarvon and Davis Pond freshwater diversions in 2010 in response to the spill resulted in prolonged periods of low salinity $(<3 \%)$ in much of CSAs 1S and 3, respectively, in Louisiana (Fig. 9; Rouhani \& Oehrig 2015). Prolonged exposure to low salinity $(<5 \%)$ can induce mortality in oysters and can inhibit feeding, growth, and spawning (Loosanoff 1953, Kennedy et al. 1996, Powers et al. 2017a, this Theme Section). Powers et al. (2017a) modeled the effect of consecutive days of exposure to $<5 \%$ between April and November on oyster survival using experimentally deployed oysters throughout southern 


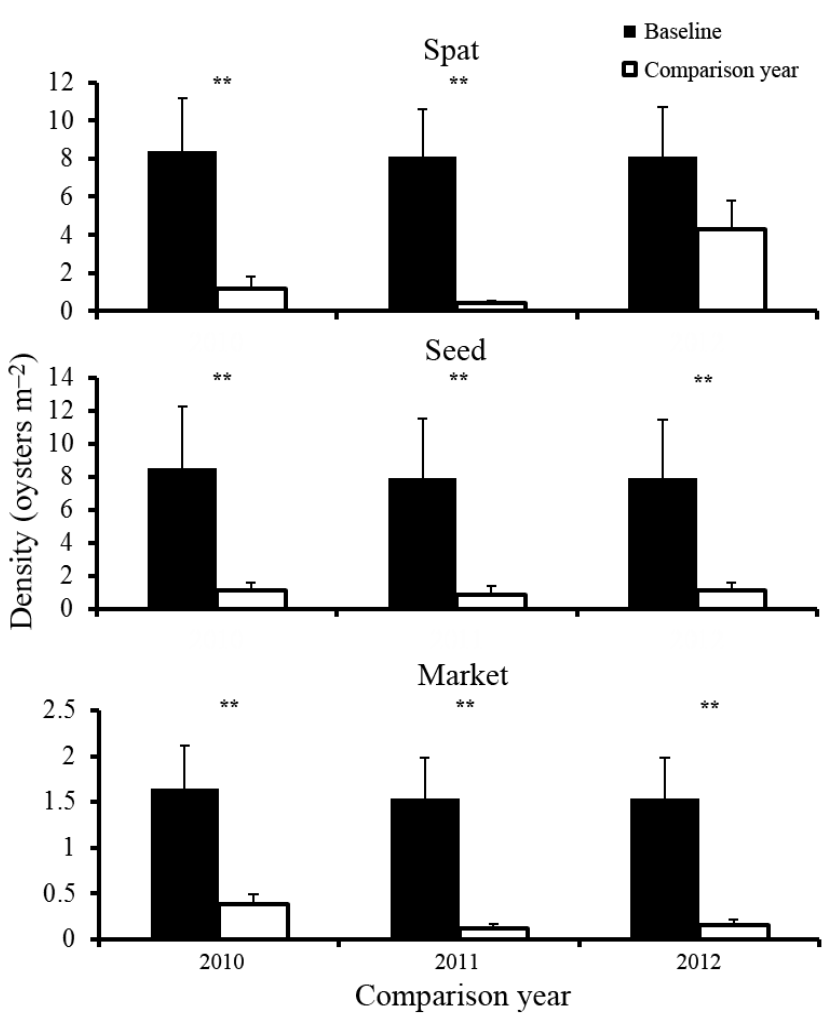

Fig. 6. As in Fig. 2, but for CSA 1N, Louisiana

Louisiana that were exposed to differing levels of low salinity. They found a sharp initial decline in oyster survival, such that $<40 \%$ of oysters survived greater than 25 consecutive days of exposure to low salinity. Meanwhile, Loosanoff (1953) revealed that oysters stopped feeding and gametogenesis at $3 \%$, and that oysters of different ages including spat were equally vulnerable to low salinity. While the optimum salinity and salinity range of egg and larval development is likely influenced by the conditions experienced by the parents during gametogenesis, these early lifehistory stages may be more vulnerable than older oysters to low salinity (Davis 1958, Kennedy et al. 1996). For instance, Davis (1958) found that adults that were held at $9 \%$ produced zygotes that developed at salinities $>7.5 \%$, and larvae from parent oysters living in higher $(26-27 \%)$ salinity water exhibited limited growth at $7.5 \%$. The Caernarvon freshwater diversion coincides with the region of the GoM east of the Mississippi River (i.e. eastern Louisiana through Mississippi) where declines in oyster densities were greatest, with $>80 \%$ declines in almost all categories of oysters persisting $2 \mathrm{yr}$ after the spill in eastern Louisiana.

Immediately after the spill in 2010, there were declines in spat and seed oysters in CSA 3, but not

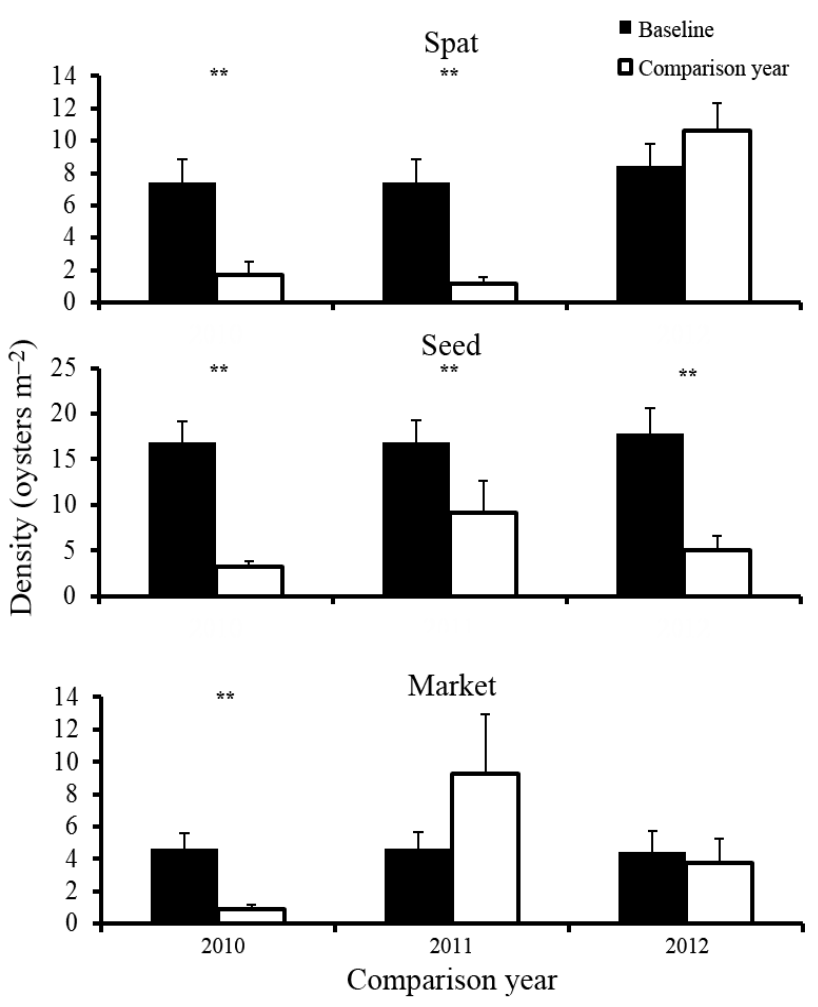

Fig. 7. As in Fig. 2, but for Mississippi Sound, Mississippi

adult oysters, and these declines in juvenile oysters did not persist beyond 2010. This failure to detect impacts to adult oysters in 2010 and all size classes beyond 2010 could stem in part from the low number of sites (6) that were surveyed in CSA 3, with all but 1 site being highly aggregated in the western portion of the region (Fig. 1). In contrast, 29 sites in CSA 1S met the criteria for inclusion in our analyses, and they were dispersed throughout this region. Impacts along the edge (i.e. western Louisiana and Apalachicola Bay, Florida) of the spill footprint (i.e. where oil-on-water and shoreline oiling occurred) were less severe. For instance, significant declines in marketsize but not juvenile oysters were observed in 2010 in CSAs 7-4 in Louisiana and Apalachicola Bay, Florida. Furthermore, indices of oyster abundances in Texas, which is west of the spill footprint, did not decline in 2010 immediately after the spill occurred.

The decline in oyster abundances that the state surveys revealed throughout the oil spill area may be in part a response to other environmental impacts that occurred during the post-spill period: First, the opening of the Bonnet Carre and Morganza spillways in 2011 to alleviate pressure on the levee system in Louisiana has been posited as a potential 


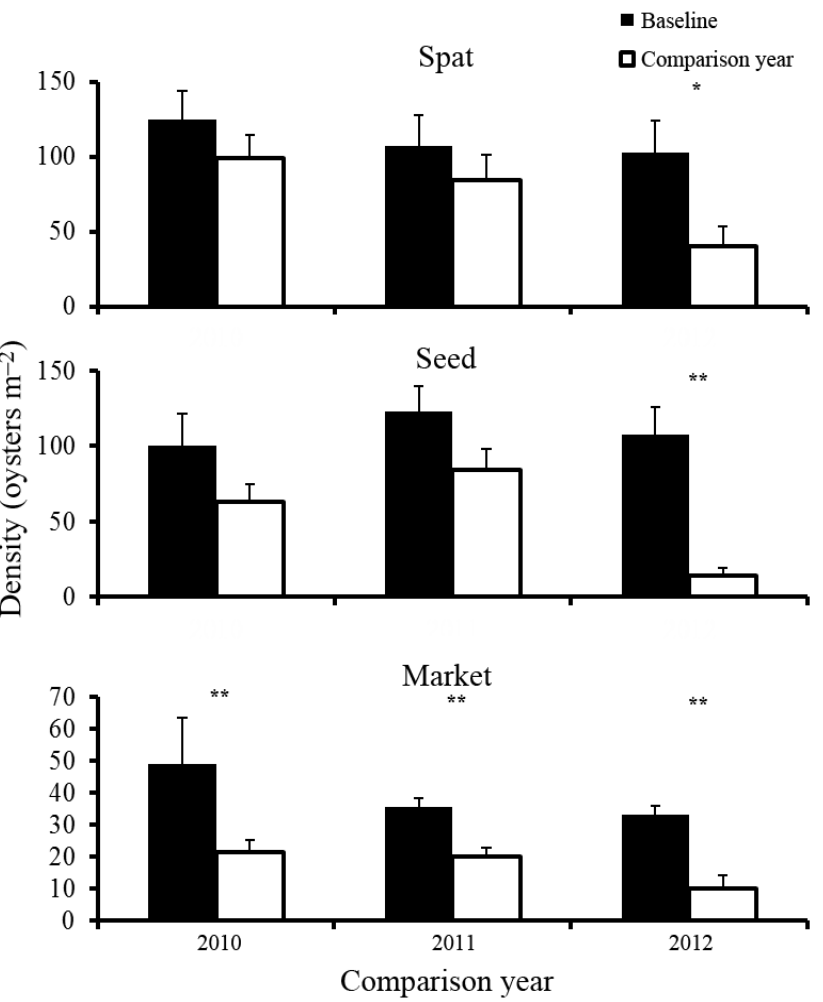

Fig. 8. As in Fig. 2, but for Apalachicola Bay, Florida

source of oyster mortality (Rouhani \& Oehrig 2015). Given that continued exposure to salinity $<5 \%$ can induce mortality (Powers et al. 2017a), these freshwater releases may have induced additional mortality. However, the declines in oyster abundances in

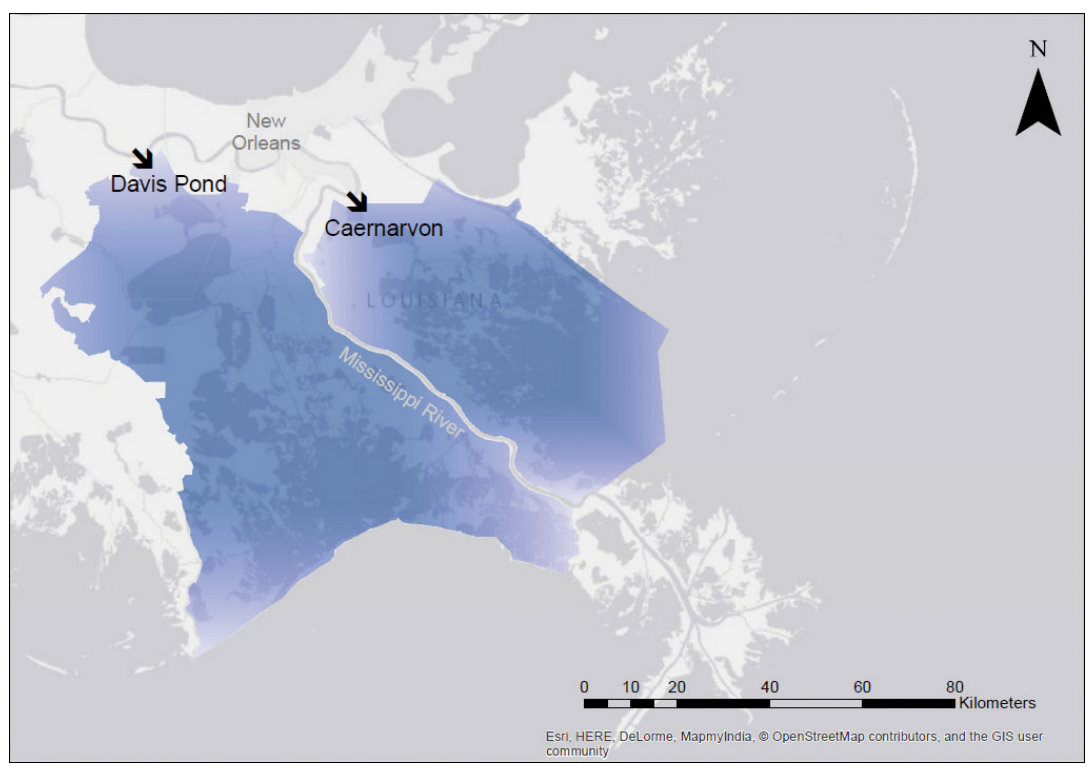

Fig. 9. Caernarvon and Davis Pond freshwater diversions in Louisiana, open in 2010, displaying the direction of freshwater discharge (arrows) and the outfall regions (shaded regions) the regions impacted by these openings, CSA $1 \mathrm{~N}$ in Louisiana and Mississippi Sound, largely began occurring in 2010 prior to the opening of these spillways.

Second, when estimating anthropogenic impacts from oiling and other activities on harvested species, it is important to consider if changes in fishing pressure may have influenced impacted populations. In 2010, Louisiana, Mississippi, and Alabama closed their coastal waters to oyster harvesting in response to the threat of oiling, which consequently reduced oyster fishing mortality in these regions. In contrast to these oil-induced closures, the commercial fisheries in Florida and Texas remained open in 2010. Adult oyster abundances may have declined in Florida in 2010 after the spill in part as a result of increased fishing in this region to compensate for reduced harvesting in the closed regions and in anticipation of a looming anthropogenic perturbation even though no evidence of oiling has been found in Apalachicola Bay (Havens et al. 2013, Camp et al. 2015). Collectively, our results suggest that the magnitude of impact from the oiling and response activities might be underestimated since fishing decreased in the most heavily impacted areas relative to previous years and after the spill in less impacted areas (Galveston Bay, Texas, and Apalachicola Bay, Florida).

Third, oyster population dynamics in the GoM and elsewhere are largely influenced by salinity. Because higher salinities within estuaries increase oyster diseases, parasites, and predators, intermediate salinities are thought to promote higher oyster survival and potentially greater fishery productivity (Wilber 1992, Buzan et al. 2009, Seavey et al. 2011, Garland \& Kimbro 2015; but see Turner 2006, 2009). The Apalachicola Bay oyster fishery collapsed in 2012 likely as a consequence of consistent low river flow leading to increased salinity, increased oyster parasites and predators, elevated oyster mortality, and eventual recruitment failure and population collapse (Oczkowski et al. 2011, Petes et al. 2012, Havens et al. 2013, Camp et al. 2015). Even after accounting for this and other confounding factors that differed among regions, we found elevated levels of oyster mortality after the DWH oil spill predominately in the regions that were most heavily impacted by it. 
Human activities have been disturbing ecosystems globally for millennia, which challenges efforts to establish pre-disturbance baselines (Jackson et al. 2001). The GoM experienced several natural and anthropogenic disturbances in the decade prior to DWH, including droughts and hurricanes Katrina and Rita. Many of the state surveys of oyster densities extend well before the $4 \mathrm{yr}$ period that we selected, but we chose this period as a baseline that included both wet and dry years. It is important to include longer time periods to estimate baseline levels due to the interannual variability in abiotic and biotic processes that influence the population dynamics of marine species. Conversely, selecting data from an individual year may not be indicative of future oyster performance, thereby potentially biasing estimates of change in oyster densities after the DWH event. We excluded data collected before 2006 in our baseline period due to hurricanes Katrina and Rita. These storms altered the environment to such a magnitude that data collected before 2006 may not be an appropriate baseline for conditions prior to the DWH event. Although the fisheries-independent surveys that were used in this study focused on subtidal oyster reef habitat, similar impacts may have transpired on intertidal oyster reefs in these regions where oil impacts and response activities were highest. However, differences in the physical environments of intertidal and subtidal oyster reefs in part explain why submergence largely influences oyster growth, recruitment, disease susceptibility, and survival (Fodrie et al. 2014, Solomon et al. 2014). Thus, intertidal reefs may respond to and recover from anthropogenic stressors such as oil spills very differently than do subtidal reefs. This difference may explain why Dietl \& Durham (2016) found that the average size of living and dead oysters did not differ between oiled and unoiled intertidal reefs. Yet, Powers et al. (2017b, this Theme Section) found that impacts of oiling resulted in the reduction of oyster habitat by up to $77 \%$ in areas that experienced heavy oiling. Thus, while oiling may not have affected the average size of living oysters, degradation of this important habitat likely resulted in the loss of important ecosystem services.

In conclusion, we found that significant declines in all size-classes of oysters occurred in eastern Louisiana through Mississippi. These regions experienced declines in oyster densities that largely did not recover during the post-spill period monitored in this study. Moreover, continued low recruitment coupled with low densities of adult oysters well after the spill could indicate that recruitment failure is occurring in this region. Because each GoM state conducts fisheries-independent surveys, spatial and temporal data were available to compare before and after the spill in control and impacted areas, similar to a BACI design. These surveys are extremely valuable for protecting state public resources such as oyster reef habitat from unexpected impacts like the DWH oil spill.

Acknowledgements. This paper would not have been possible without the excellent fisheries-independent datasets that were collected and provided by resource agencies in Texas, Louisiana, Mississippi, Alabama, and Florida. We thank Shay Howlin and Jessica Murray for assistance with creating the maps for this manuscript, Jacob Oehrig for assistance with statistical analyses, and Mark Luckenbach, Ian Zelo, and Mary Baker for reviewing and providing feedback on the early drafts of this manuscript. We dedicate this article in memory of our dear colleague and friend Amelia Geggel.

\section{LITERATURE CITED}

Breitburg DL, Coen LD, Luckenbach MW, Mann R, Posey M, Wesson JA (2000) Oyster reef restoration: convergence of harvest and conservation strategies. J Shellfish Res 19:371-377

Buzan D, Lee W, Culbertson J, Kuhn N, Robinson L (2009) Positive relationship between freshwater inflow and oyster abundance in Galveston Bay, Texas. Estuaries Coasts 32:206-212

Camp EV, Pine Iii WE, Havens K, Kane AS and others (2015) Collapse of a historic oyster fishery: diagnosing causes and identifying paths toward increased resilience. Ecol Soc 20:45

Carmichael RH, Walton W, Clark H (2012) Bivalveenhanced nitrogen removal from coastal estuaries. Can J Fish Aquat Sci 69:1131-1149

Carroll J, Gobler CJ, Peterson BJ (2008) Resource-restricted growth of eelgrass in New York estuaries: light limitation, and alleviation of nutrient stress by hard clams. Mar Ecol Prog Ser 369:51-62

Coen LD, Luckenbach MW, Breitburg DL (1999) The role of oyster reefs as essential fish habitat: a review of current knowledge and some new perspectives. Am Fish Soc Symp 22:438-454

Davis HC (1958) Survival and growth of clam and oyster larvae at different salinities. Biol Bull 114:296-307

*Dietl GP, Durham SR (2016) Geohistorical records indicate no impact of the Deepwater Horizon oil spill on oyster body size. R Soc Open Sci 3:160763

Everett RA, Ruiz GM, Carlton JT (1995) Effect of oyster mariculture on submerged aquatic vegetation: an experimental test in a Pacific Northwest estuary. Mar Ecol Prog Ser 125:205-217

Fodrie FJ, Able KW, Galvez F, Heck KL Jr and others (2014) Integrating organismal and population responses of estuarine fishes in Macondo spill research. Bioscience 64: 778-788

Garland HG, Kimbro DL (2015) Drought increases consumer 
pressure on oyster reefs in Florida, USA. PLOS ONE 10: e0125095

* Grabowski JH, Hughes AR, Kimbro DL, Dolan MA (2005) How habitat setting influences restored oyster reef communities. Ecology 86:1926-1935

Grabowski JH, Brumbaugh RD, Conrad R, Keeler AG and others (2012) Economic valuation of ecosystem services provided by oyster reefs. Bioscience 632:900-909

Harding JM, Mann R (2001) Oyster reefs as fish habitat: opportunistic use of restored reefs by transient fishes. J Shellfish Res 20:951-959

Havens K, Allen M, Camp E, Irani T and others (2013) Apalachicola Bay oyster situation report. TP-200. Florida Sea Grant, University of Florida, Gainesville, FL. https://www.flseagrant.org/wp-content/uploads/tp200_ apalachicola_oyster_situation_report.pdf

Jackson JBC, Kirby MX, Berger WH, Bjorndal KA and others (2001) Historical overfishing and the recent collapse of coastal ecosystems. Science 293:629-637

Kellogg ML, Cornwell JC, Owens MS, Paynter KT (2013) Denitrification and nutrient assimilation on a restored oyster reef. Mar Ecol Prog Ser 480:1-19

Kennedy VS, Newell RIE, Eble AF (eds) (1996) The eastern oyster: Crassostrea virginica. Maryland Sea Grant College, College Park, MD

LA-DWF (Louisiana Department of Wildlife and Fisheries) (2011) Oyster stock assessment report. Oyster Data Report Series. www.wlf.louisiana.gov/sites/default/files/ pdf/document/37757-stock-assessments/2011_oyster_ stock_assessment.pdf

Loosanoff VL (1953) Behavior of oysters in waters of low salinity. Proc Natl Shellfish Assoc 1952:135-151

Michel J, Owens EH, Zengel S, Graham A and others (2013) Extent and degree of shoreline oiling: Deepwater Horizon oil spill, Gulf of Mexico, USA. PLOS ONE 8:e65087

Moran MD (2003) Arguments for rejecting the sequential Bonferroni in ecological studies. Oikos 100:403-405

National Research Council (2013) An ecosystem services approach to assessing the impacts of the Deepwater Horizon Oil Spill in the Gulf of Mexico. National Academies Press, Washington, DC

Newell RIE (1988) Ecological changes in Chesapeake Bay: Are they the result of overharvesting the American oyster, Crassostrea virginica? In: Lynch MP, Krome EC (eds) Understanding the estuary: advances in Chesapeake Bay research. Publication 129. Chesapeake Research Consortium, Baltimore, MD, p 536-546

Newell RIE, Koch EW (2004) Modeling seagrass density and distribution in response to changes in turbidity stemming from bivalve filtration and seagrass sediment stabilization. Estuaries 27:793-806

*Newell RIE, Cornwell JC, Owens MS (2002) Influence of simulated bivalve biodeposition and microphytobenthos on sediment nitrogen dynamics: a laboratory study. Limnol Oceanogr 47:1367-1379

* Oczkowski AJ, Lewis FG, Nixon SW, Edmiston HL, Robinson RS, Chanton JP (2011) Fresh water inflow and oyster productivity in Apalachicola Bay, FL (USA). Estuaries Coasts 34:993-1005

* OSAT (Operational Science Advisory Team) (2010) Summary report for sub-sea and sub-surface oil and dispersant detection: sampling and monitoring. Prepared for Paul F. Zukunft, Federal On-Scene Coordinator, Deepwater Horizon MC252. https://www.restorethegulf.gov/ sites/default/files/documents/pdf/OSAT_Report_FINAL_
17DEC.pdf

*Peterson CH, Lipcius RN (2003) Conceptual progress towards predicting quantitative ecosystem benefits of ecological restorations. Mar Ecol Prog Ser 264:297-307

*Peterson CH, Grabowski JH, Powers SP (2003) Estimated enhancement of fish production resulting from restoring oyster reef habitat: quantitative valuation. Mar Ecol Prog Ser 264:249-264

* Petes LE, Brown AJ, Knight CR (2012) Impacts of upstream drought and water withdrawals on the health and survival of downstream estuarine oyster populations. Ecol Evol 2:1712-1724

Piazza BP, Banks PD, La Peyre MK (2005) The potential for created oyster shell reefs as a sustainable shoreline protection strategy in Louisiana. Restor Ecol 13:499-506

* Piehler MF, Smyth AR (2011) Impacts of ecosystem engineers on estuarine nitrogen cycling. Ecosphere 2:art12

Powell EN, Ashton-Alcox KA, Dobarro JA, Cummings M, Banta SE (2002) The inherent efficiency of oyster dredges in survey mode. J Shellfish Res 21:691-695

Powers SP, Grabowski JH, Roman H, Geggel A, Rouhani S, Oehrig J, Baker M (2017a) Consequences of large-scale salinity alteration during the Deepwater Horizon oil spill on subtidal oyster populations. Mar Ecol Prog Ser 576: 175-187

Powers SP, Rouhani S, Baker MC, Roman H and others (2017b) Ecosystem services are lost when facilitation between two ecosystem engineers is compromised by oil. Mar Ecol Prog Ser 576:189-202

Rouhani SR, Oehrig J (2015) Methodology used to determine the spatial extent of fresh water impact in Davis Pond and Caernarvon Basins in 2010. Tech Memo NS_TR_07. www.fws.gov/doiddata/dwh-ar-documents/ 901/DWH-AR0270373.pdf

* Seavey JR, Pine WE, Frederick P, Sturmer L, Berrigan M (2011) Decadal changes in oyster reefs in the Big Bend of Florida's Gulf Coast. Ecosphere 2:art114

* Smyth AR, Thompson SP, Siporin KN, Gardner WS, McCarthy MJ, Piehler MF (2013) Assessing nitrogen dynamics throughout the estuarine landscape. Estuaries Coasts 36:44-55

Solomon JA, Donnelly MJ, Walterst LJ (2014) Effects of sea level rise on the intertidal oyster Crassostrea virginica by field experiments. J Coast Res 68:57-64

* Soniat TM, Finelli CM, Ruiz JT (2004) Vertical structure and predator refuge mediate oyster reef development and community dynamics. J Exp Mar Biol Ecol 310:163-182

Tolley SG, Volety AK (2005) The role of oysters in habitat use of oyster reefs by resident fishes and decapod crustaceans. J Shellfish Res 24:1007-1012

Turner RE (2006) Will lowering estuarine salinity increase Gulf of Mexico oyster landings? Estuaries Coasts 29: 345-352

* Turner RE (2009) Comments on Buzan et al. 'Positive relationships between freshwater inflow and oyster abundance in Galveston Bay, Texas'. Estuaries Coasts 32: 213-217

* Underwood AJ (1989) The analysis of stress in natural populations. Biol J Linn Soc 37:51-78

US District Court (2014) Findings of fact and conclusions of law: Phase One Trial. In re: Oil Spill by the Oil Rig 'Deepwater Horizon' in the Gulf of Mexico, on April 20, 2010, No. MDL 2179, Section 7 (Revised September 9, 2014) (Doc 13355, Fig. 1). United States District Court for the Eastern District of Louisiana, New Orleans, LA 
US District Court (2015) Findings of fact and conclusions of law: Phase Two Trial. In re: Oil Spill by the Oil Rig 'Deepwater Horizon' in the Gulf of Mexico, on April 20, 2010, No. MDL 2179, 2015 WL 225421 (LA E.D. Jan. 15, 2015) (Doc 14021). United States District Court for the Eastern District of Louisiana. www.gulfspillrestoration.noaa. gov/sites/default/files/wp-content/uploads/Chapter-2_

Editorial responsibility: Myron Peck,

Hamburg, Germany
Incident-Overview_508.pdf

*Wall CC, Peterson BJ, Gobler CJ (2008) Facilitation of seagrass Zostera marina productivity by suspension-feeding bivalves. Mar Ecol Prog Ser 357:165-174

*Wilber DH (1992) Associations between freshwater inflows and oyster productivity in Apalachicola Bay, Florida. Estuar Coast Shelf Sci 35:179-190

Submitted: January 6, 2017; Accepted: May 22, 2017

Proofs received from author(s): July 9, 2017 